Jurnal Ekonomi dan Perbankan Syariah

Vol. 8 . No 1, April 2020; 28-43 ISSN (printed): 2355-1755 | ISSN (online): 2579-6437

DOI: https://doi.org/10.46899/jeps.v8i1.174

\title{
The Effect of E-Marketing with the AISAS Model on Shariah Mutual Fund Investment Decisions at Bibit Mutual Fund Fintech
}

\author{
Iin Mega Nur Janah', Iqbal Fadli Muhammad², Muhammad Doddy AB ${ }^{3}$
}

${ }^{1}$ SEBI: Email: iinmega03@gmail.com

${ }^{2} S E B I$ Lecturer Email: qbalfm37@gmail.com

${ }^{3}$ SEBI Lecturer \& Doctoral Candidate AeU Malaysia Email:: doddy.abe@ gmail.com

\begin{abstract}
This study aims to examine the effect of E-marketing with the AISAS model on mutual fund investment decisions. This research using quantitative research. Data was obtained by distributing online questionnaires to 34 respondents who had or were investing in Bibit Mutual Fund Fintechs that had been registered in the OJK. The sampling technique in this study is purposive sampling, while the Structural Equation Modeling (SEM) with the Partial Least Square (PLS) approach is using a data analysis technique. Based on the results of data analysis, Attention variable has a significant effect on Interest variable, Interest variable has a significant effect on Search variable, Search variable has a significant effect on Action variable, Action variable has a significant effect on Share variable, and Share variable has a significant effect on Investment Decisions.
\end{abstract}

Keywords: E-Marketing; Investment Decisions; AISAS Model

\section{INTRODUCTION}

In today's digital era, the pattern of people's lives is greatly influenced by technological advances that offer convenience in finding information, providing easy and fast service access for people, individuals and companies (Harefa \& Kennedy, 2018). Technological progress will run in line with the advancement of science, currently the world has entered the era of the fourth revolution or industrial revolution 4.0. In this era, there was a big leap in the advancement of technology, information and communication (Riskinanto, Kelana, \& Hilmawan, 2017). The development of technology has a big impact in various fields of life. Information technology has changed the paradigm in various activities, creating innovations and new business opportunities, which will produce new types of jobs and careers in human life (Fariana \& Safii, 2018).

The 4.0 industrial revolution gave birth to new innovations in various fields, such as education, social, culture, lifestyle, economy and others (Dz, 2018). Financial technology is one of the new breakthroughs from the existence of technological advances in the economic field (Amer, Barberis, \& Buckley, 2016). Financial technology provides new innovations in the field of financial services, which means that financial technology has an important role 
Jurnal Ekonomi dan Perbankan Syariah

Vol. 8. No.1, April 2020: 28-43 ISSN (printed): 2355-1755 | ISSN (online): 2579-643

in the ongoing activities of the Indonesian economy (Harefa \& Kennedy, 2018).

Financial technology is also known as Fintech (Bank Indonesia, 2017). In simple terms, fintech can be interpreted as the use of technology and information to develop the financial industry (OJK, 2017). Various innovations from fintech, ranging from payments, transfers, financing to investment, can also be done with an existing application. Fintech in this sector includes Peer-to-Peer (P2P) Lending, Crowdfunding, Supply Chain Finance and others. Companies engaged in this field also compete to maintain their business continuity by innovating and developing information technology in selling their products (OJK 2017).

Referring to the data presented by (APJII 2019) the number of internet users continues to increase from year to year. In 2014 internet users in Indonesia had not reached 100 million users, but in 2015 internet users in Indonesia had increased by $22.1 \%$ to become 110.2 million and in 2017 internet users in Indonesia had reached 143.26 million by 2018. increased to 171.17 million users.

From the data obtained through (APJII 2019) it is also known that in a new report from Google and Temsek, Indonesia is one of the countries with the fastest digital economic growth in the Southeast Asian region in the last five years. Indonesia grew five times compared to 2015 which grew by US \$ 8 billion. From this data, it is known that Indonesia has scored US $\$ 40$ billion in the digital economy sector, this figure is higher than Thailand which is only US \$ 16 billion, Singapore (US \$ 12 billion), Vietnam (US \$ 12 billion), Malaysia (US \$ 11 billion), and the Philippines (US $\$ 7$ billion). With an average growth of 49 percent per year, the achievement of Indonesia's digital economy is even believed to penetrate US \$ 130 billion by 2025 .

With the development of the digital economy in Indonesia, it means that the Indonesian people really take advantage of the advancement of technology, as evidenced by the very rapid growth of the digital economy in Indonesia and the increasing number of digital-based services. Based on data provided by Fintech Indonesia Report 2018 - The state of Play for Fintech Indonesia (2018). Fintech Indonesia list is grouped into several categories including 65 Fintech Payment, Fintech Landing as many as 49, Crowdfunding as many as 7, Crypto \& Blockchain as many as 4, 2 platforms in the Accounting category, 7 in the POS System category, Personal Finance \& Wealth Management as many as 13 , Comparison as many as 12, and Insurtech for 10 .

Fintech has evolved in three periods. 2008 until now is the third period of the development of fintech in Indonesia. During this period, there was a surge in the number of start-up companies in the financial services sector. From the data (Financial Services Authority 2019) as of August 7, 2019 the total number of registered and licensed fintech operators was 127 companies, 9 of which were sharia-based fintech. As of October 30, 2019, there has been an increase in the number of registered and licensed fintech operators, namely 144 companies, 12 of which are sharia fintech. As regulated in the fatwa (DSN- 
31 |lin Mega Nur Janah, Iqbal Fadli Muhammad, Muhammad Doddy : The Effect of EMarketing with the AISAS Model on Sharia Mutual Fund Investment Decision...

MUI, 2018) No: 117 / DSN_MUI / II / 2018 concerning Information Technology-Based Financing Services Based on Sharia Principles.

Of the various types of fintech that exist, this study will only discuss Peer-to-Peer Lending fintech with investment products in the form of Islamic mutual funds. In this case, Islamic mutual funds take advantage of the fintech market place in selling Islamic mutual funds. According to the Chief Executive of Capital Market Supervision of the Financial Services Authority (OJK) Hoesen, the use of fintech in the sale of Islamic mutual funds has increased the number of new accounts in the capital market, which has already obtained more than 120 thousand new accounts (Republika, 2018).

OJK Deputy Director of Investment Management, Halim Haryono, said, In a period of 3 years, namely from 2016 to 2018, online purchase subscriptions have increased significantly. The increase in the online mutual fund market has directly increased transactions in the Indonesian capital market. Therefore, OJK fully supports online distribution of mutual fund marketing (Liputan 6, 2019). One of the important things in introducing investment products is access. Technological progress is a breakthrough to expand investor access to investment products. This convenience has sparked investor interest in investing in mutual funds (Technologue.id, 2018). OJK recorded 62 Mutual Fund Selling Agents (APERD), consisting of 31 banks, 21 securities, and 10 fintech.

Bibit is a fintech company that presents an online mutual fund investment application that will help investors choose the best mutual funds, PT Bibit Tumbuh Bersama acts as a Mutual Fund Selling Agent (APERD) registered and supervised by the Financial Services Authority. Bibit offers digital account opening and can be completed in a matter of minutes, without having to use a form, financial planner and without a spreadsheet, besides that seeds also offer benefits in the form of free commission fees, minimal investment funds that can start with only IDR 10,000, can withdraw investment at any time, and not taxed.

After seeing that mutual fund users continue to grow along with the increasing number of internet users, the researchers wanted to find out whether online promotion or electronic marketing had an effect on increasing the number of investors in sharia mutual funds.

Electronic Marketing itself is a marketing system that utilizes information and communication technology on an internet basis, E-marketing can be used to market a product, E-marketing systems are felt to be easier, and quickly hit the targeted consumers, plus now smartphone users are very many, it will be directly proportional to the increasing internet users.

At present investment products such as mutual funds utilize emarketing in marketing their products, one of the fintech companies that utilize e-marketing in marketing their products is Bibit (PT Bibit Tumbuh Bersama). These companies take advantage of online promotions through the internet and social media, such as the Website, YouTube, Instagram, Facebook and Twitter.

This study aims to see consumer responses to online promotions, which can be described using the AISAS model (Attention, Interest, Search, 
Jurnal Ekonomi dan Perbankan Syariah

Vol. 8. No.1, April 2020: 28-43 ISSN (printed): 2355-1755 | ISSN (online): 2579-643

Action, Share). The AISAS model emerged as the culture of society in using the internet changed. The AISAS model is a consumption behavior model that takes into account the components of the internet in it.

In this study, researchers used the AISAS model in describing the role of E-Marketing in promoting Islamic mutual fund investment in fintech companies, so that investors are interested and can increase the amount of Islamic mutual fund investment through fintech companies, with the research title "The Effect of E-Marketing With AISAS Model on Investment Decisions. Sharia Mutual Funds at Bibit Mutual Funds Fintech. "

\section{LITERATURE REVIEW}

\section{A Brief description of PT Bibit Tumbuh Bersama (Bibit)}

Bibit is an online mutual fund supermarket, where the seeds serve as agents who help to sell mutual fund products from the investment manager. The fundamental difference between Bibit and other fintech is the application of the principles of Modern Portfolio Theory in designing the portfolio of each investor, so that the portfolio quality of each investor in Bibit can be more optimal because it has been well diversified according to the risk profile of each investor.

PT Bibit Tumbuh Bersama has obtained a license from the Financial Services Authority with Number KEP-14 / PM2.1 / 2017 on October 6, 2017. Bibit offers digital account opening and can be completed in minutes, without having to use forms, financial planner and without spreadsheet, besides that seeds also offer the advantages of free commission fees, minimal investment funds, which can start with only IDR 10,000, can withdraw your investment at any time, and is not taxed.

In marketing their products, seeds take advantage of social media such as Instagram, Twitter, Facebook and Telegram. Each of the Bibit accounts on social media has a high following. The seed.id Instagram account has 85.4 thousand followers, the @ bibitid Twitter account has 13.3 thousand followers, and the Bibit application has been downloaded more than 500,000 times.

From the explanation above, we can see that Bibit investment platform makes great use of social media in marketing its products, which can be seen from the number of followers on social media accounts and also their interactions with investors and potential investors through social media.

\footnotetext{
AISAS

Consumption Behavior of consumers in consuming products that have been known for a long time is AIDA (Attention, Interest, Desire, Action). This model eventually developed until other forms emerged, including AIDMA (Attention, Interest, Desire, Memory, Action), which is more concentrated on the consumption behavior model in the broadcasting world (Wisnu \& Hapsari, 2016).

In the end, now AISAS (Attention, Interest, Search, Action, Share) appears, which is a consumption behavior model that was initiated by Dentsu in 2004. This model emerged after the rapid development of the internet in the
} 
33 | lin Mega Nur Janah, Iqbal Fadli Muhammad, Muhammad Doddy : The Effect of EMarketing with the AISAS Model on Sharia Mutual Fund Investment Decision...

global world. AISAS is more concentrated on how the consumption of goods and services is carried out, one of which is due to the large role of the internet (Wisnu \& Hapsari, 2016).

In this model, Dentsu sees that the share points are different from other consumption behavior models. This share emerged as a result of the enormous internet reach for the products and services in its promotion. The power of this share is used by marketers to reach more consumers. This is very possible because the internet contains real time characteristics because at the same time, the whole world can access the information that is presented. Currently, time and geographical differences are no longer a barrier to the breadth of information coverage (Wisnu \& Hapsari, 2016). From the description above, it can be concluded that technological advances have changed the human paradigm in consuming goods and services. By using the internet and social media will expand the promotion of an item or service, focusing on shares. (Wisnu \& Hapsari, 2016) wrote in their research that without realizing it, the role of word of mouth (WOM) is also applied. Herein lies how AISAS comes up with an online consumption behavior model, which takes the power of the internet in expanding information.

\section{AISAS steps}

AISAS itself stands for Attention, Interest, Search, Action, and Share. AISAS is intended as a reflection of the large role the internet plays in human life in the present era. Search and share positions are important activities on the internet in seeking information in the form of user experience, service levels, and satisfaction. Following is an explanation of each step of the AISAS model (Sugiyama, 2011):

1. Attention

The purpose of this phase is to increase consumer attention to a product. A product must be introduced to its target market. With the advent of the internet era, the choice of introducing products can be made through a variety of relatively inexpensive ways, such as via email, mailing lists, and online media.

2. Interest

Interest is the process when potential customers become interested in our products. This interest can occur because of the right communication for consumers. in the era of the internet, this interest can also occur when consumers feel attracted to the information displayed in the online media used.

3. Search

Search is a process where consumers will try to find as much information as possible through search engines before making a decision. Product reviews can be clearly found on the internet through various forms, for example through the media Twitter, Facebook, Instagram, YouTube and blogs.

4. Action 
Jurnal Ekonomi dan Perbankan Syariah

Vol. 8. No.1, April 2020: 28-43 ISSN (printed): 2355-1755 | ISSN (online): 2579-643

Action is an action where consumers make a purchase action. This is where the real experience can be created, where consumers have experienced the product or service. In this section also the process of direct interaction that occurs between consumers and sellers. The purpose of this phase is to provide an opportunity for consumers to purchase the product.

5. Share

Share is the result that will be obtained after consumers feel all the experiences of their interactions with the product or brand, they will share their experiences with others through online media. The purpose of this phase is to encourage consumers to send quality information about the products they consume.

\section{Framework}

To find out the relationship between the role of e-marketing and investment decisions for Islamic mutual funds in the fintech Bibit mutual funds using the AISAS model, a frame of mind is made as in the following figure;

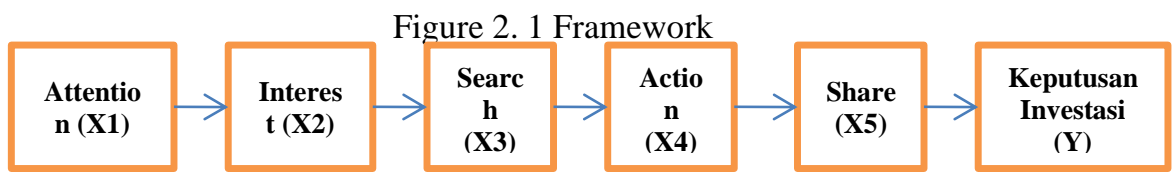

\section{Hypothesis}

According to (Umar, 2013) a hypothesis is a temporary formulation of something that is made to explain it and can also guide / direct further investigations. The hypotheses in this study are:

Hypothesis 1: Attention (X1) affects Interest (X2).

Hypothesis 2: Interest (X2) affects Search (X3).

Hypothesis 3: Search (X3) influences Action (X4).

Hypothesis 4: Action (X4) affects Share (X5).

Hypothesis 5: Share (X5) affects investment decisions (Y).

\section{RESEARCH METHODOLOGY}

\section{Object of research}

The object of this research is the Fintech Mutual Fund Seed Company, which is an online mutual fund supermarket company, where the seedlings serve as agents who help to sell mutual fund products from the Investment Manager.

\section{Types of research}

This research is a type of quantitative research. According to (Priyono, 2016) the use of quantitative research will identify the relationship 
35 |lin Mega Nur Janah, Iqbal Fadli Muhammad, Muhammad Doddy : The Effect of EMarketing with the AISAS Model on Sharia Mutual Fund Investment Decision...

between variables with research data in the form of numbers and analysis using statistics.

This quantitative research uses a survey method. The survey research method is used to measure the existing symptoms, because it will use existing data to solve problems (Umar, 2013). The survey method is used to describe the relationship between the causal variables studied.

This research method aims to determine and analyze how the relationship between the effects of e-marketing using the AISAS model on investment decisions in fintech mutual funds Bibit. This survey was conducted for people who have invested in fintech mutual funds Bibit by distributing questionnaires to samples of respondents to obtain relevant facts about causal relationships and hypotheses.

The variables in this study use five independent variables: Attention, Interest, Search, Action, Share, and one dependent variable: investment decisions in Islamic fintech. This research was conducted to determine the effect of the independent variable on the dependent variable.

\section{Data Type}

Sources of data used in this study are primary and secondary data. According to Mc.Leod in the book (Umar, 2013) primary data is data obtained from the first source either from individuals or individuals such as the results of interviews or the results of filling out questionnaires that are usually carried out by researchers. Meanwhile, secondary data is primary data that has been further processed and presented either by primary data collectors or by other parties, for example in the form of tables or diagrams.

Thus, it can be interpreted that primary data is data that is obtained directly from the source, and secondary data is data obtained through libraries or documents containing data whose validity has been guaranteed. Primary data in this study were obtained by researchers directly from the original source (not through intermediaries), while the primary data in this study were obtained from distributing questionnaires to respondents. Respondents in this study amounted to 34 respondents. While secondary data is data obtained from second parties or data obtained through intermediary media or indirectly which in this study were obtained from various agencies such as the OJK and APJII, literature studies, journals, books, reports, articles of previous research results, and searches Through the internet.

\section{Population and Sample}

According to Bailey in (Priyono, 2016) population is the whole symptom / unit to be studied. Meanwhile, the sample is part of the population that wants to be studied. Therefore, the sample must be seen as a predictor of the population and not the population itself.

The population in this study is infinite, that is, all people who have invested in Islamic mutual funds fintech. This study limits the population to people who have been and are currently investing in Islamic fintech mutual funds that have been registered with the OJK, namely Bibit (PT Bibit Tumbuh 
Jurnal Ekonomi dan Perbankan Syariah

Vol. 8. No.1, April 2020: 20-43 ISSN (printed): 2355-1755 | ISSN (online): 2579-643

Bersama). To make it easier for researchers to obtain data, samples were taken which were included in the members of the population. In line with this, the sampling in this study followed the determination of the sample size.

\section{Method of data collection}

In this study, using a data collection technique in the form of a questionnaire which is a data collection by providing or distributing a list of questions or statements to respondents in the hope of providing a response to the list of questions (Umar, 2013). Therefore, a questionnaire can also be interpreted as a data collection technique by compiling the questions and answers that respondents need in a study.

\section{Measure Scale}

In this study using a Likert scale. The Likert scale is a scale based on the sum of the respondents' attitudes in responding to statements related to the indicators of a concept or variable being measured (Wiley, 2017). According to Kinnear in (Umar, 2013) the Likert scale relates to statements about someone's attitude towards something, for example agreeing — disagreeing, happy-unhappy and good-unkind. Respondents were asked to fill out statements on an ordinal scale (some experts say the interval scale) was verbal in a number of certain categories.

In the Likert scale, respondents are asked to agree or disagree with each statement. Usually the Likert scale uses five points with a normal value in the middle (third) position. For quantitative research, the answers can be scored;

Table 3.1 Scale of Measure

\begin{tabular}{|l|l|l|}
\hline Scale & Score & Information \\
\hline Strongly Agree & 5 & Very positive \\
\hline Agree & 4 & Positive \\
\hline Fairly Agree & 3 & Neutral \\
\hline Disagree & 2 & Negative \\
\hline Strongly Disagree & 1 & Very Negative \\
\hline
\end{tabular}

\section{Data analysis technique}

The data analysis technique in this study was carried out with SEM (Structural Equation Modeling) model together with the PLS (Partial Least Square) approach, where this model can test the measurement model as well as test the structural model. The measurement model is used to test the validity and reliability, while the structural model is used for the causality test (hypothesis testing with predictive models) (Abdillah \& Hartono, 2015).

This study uses the PLS approach because the author's basic assumption when using the model is prediction. In addition, PLS can be used 
37 | lin Mega Nur Janah, Iqbal Fadli Muhammad, Muhammad Doddy : The Effect of EMarketing with the AISAS Model on Sharia Mutual Fund Investment Decision...

to estimate the path model with a smaller sample size and can be used for very complex models consisting of many latent and manifest variables without experiencing problems in data estimation. This study may have a small sample size so it is more appropriate to use the SEM model with the PLS approach.

\section{Model Evaluation in PLS}

PLS model evaluation is done by evaluating the outer model and inner model. Outer model is a measurement model to assess the validity and reliability of the model. Through the algorithmic literacy process, the measurement model parameters (convergent validity, discriminant validity, composite reliability and Cronbach alpha) were obtained, including the $\mathrm{R}^{2}$ value as a parameter of the prediction model accuracy. Inner model is a structural model to predict the causality relationship between latent variables. Through the bootstrapping process, T-Statistic test parameters are obtained to predict a causality relationship (Abdillah \& Hartono, 2015).

\section{Evaluation of the Measurement Model (Outer Model)}

The measurement model is used to test the construct validity and instrument reliability. This measurement model includes convergent validity and discriminant validity through cross loading and the average root variance extracted, and composite reliability. Evaluations of measurement models are grouped into evaluations of reflective models or formative models (Abdillah \& Hartono, 2015):

\section{Convergent Validity}

Convergent validity relates to the principle that the measures of a construct should be highly correlated. Convergent validity occurs when the scores obtained from two different instruments measuring the same construct have a high correlation. Convergent validity testing in PLS with reflective indicators is assessed based on the loading factor (the correlation between the item score / component score and the construct score) the indicators that measure the construct.

The rule of thumb that is usually used to make the initial check of the factor matrix is that \pm 30 is considered to have met the minimum level, for a load of \pm 40 is considered better, and for a load of $>0.50$ is considered practically significant. Thus, the higher the factor loading value, the more important the role of loading is in interpreting the factor matrix. The rule of thumb used for Convergent validity is outer 
Jurnal Ekonomi dan Perbankan Syariah

Vol. 8. No.1, April 2020: 28-43 ISSN (printed): 2355-1755 | ISSN (online): 2579-643

loading $>0.7$, communality $>0.5$ and Average Variance Extracted $(\mathrm{AVE})>0.5$.

\section{Discriminant Validity}

Discriminant validity relates to the principle that the measures of different constructs should not be highly correlated. Discriminant Validity occurs when two different instruments that measure two constructs that are predicted to be uncorrelated produce a score that is not correlated. Discriminant Validity test is assessed based on cross loading measurements with the construct. Another method used to assess Discriminant Validity is to compare the AVE roots for each construct with the correlation between the construct and other constructs in the model. The model has sufficient discriminant validity if the AVE root for each construct is greater than the correlation between the construct and the other constructs in the model.

Table 3.2 Validity Test Parameters in the PLS Measurement Model

\begin{tabular}{|l|l|l|}
\hline Validity Test & Parameter & Rule of Thumbs \\
\hline Convergent & Loading Factors & More than 0,7 \\
\hline & $\begin{array}{l}\text { Average Variance } \\
\text { Extracted (AVE) }\end{array}$ & More than 0,5 \\
\hline & Communality & More than 0,5 \\
\hline Discriminant & $\begin{array}{l}\text { Akar AVE dan Korelasi } \\
\text { variable laten }\end{array}$ & $\begin{array}{l}\text { Root AVE Latent } \\
\text { variable correlation }\end{array}$ \\
\hline & Cross loading & $\begin{array}{l}\text { More than 0,7 in one } \\
\text { variable }\end{array}$ \\
\hline
\end{tabular}

\section{Evaluation of the Structural Model (Inner Model)}

The structural model is also known as the inner model. Structural models describe the relationship between independent (exogenous) latent variables and dependent (endogenous) latent variables. There are several stages in evaluating a structural model. The first is to see the significance of the relationship between the constructs as seen from the path coefficient with the T-Statistic test parameter through bootstrapping, to see the percentage of variance described by the $\mathrm{R}^{2}$ value (Abdillah \& Hartono, 2015).

1. Path coefficient with T-statistical test parameters

The score of the path coefficient or inner model indicated by the t-statistic value must be above 1.96 for the two-tailed hypothesis and above 1.64 for the one-tailed hypothesis for hypothesis testing at 5\% alpha and $80 \%$ power.

a. If the value of $\mathrm{t}$ count $>\mathrm{t}$ table then $\mathrm{H} 0$ is rejected and $\mathrm{H} 1$ is accepted.

b. If the value of $\mathrm{t}$ count $<\mathrm{t}$ table then $\mathrm{H} 0$ is accepted and $\mathrm{H} 1$ is rejected. 
39 |lin Mega Nur Janah, Iqbal Fadli Muhammad, Muhammad Doddy : The Effect of EMarketing with the AISAS Model on Sharia Mutual Fund Investment Decision...

\section{Coefficient of Determination $\left(\mathrm{R}^{2}\right)$}

The value of $\mathrm{R}$ square is used to measure the degree of variation in changes in the independent variable on the dependent variable. The higher the $\mathrm{R}$ square value means the better the prediction model of the proposed research model. For example, if the $\mathrm{R}$ square value is 0.7 , it means that the variation of changes in the dependent variable that can be explained by the independent variable is $70 \%$, while the rest is explained by other variables outside the proposed model.

However, $\mathrm{R}$ square is not an absolute parameter in measuring the accuracy of a predictive model because the basis of the theoretical relationship is the most important parameter to explain the causality relationship (Abdillah \& Hartono, 2015).

\section{ANALYSIS AND DISCUSSION}

From the results of statistical tests using the PLS data analysis tool, it shows that all variables have a significant effect, the Attention variable has a significant effect on the Interest variable, then the Interest variable has a significant effect on the Search variable, then the Search variable has a significant effect on the Action variable, then the Action variable has a significant effect on the Interest variable. Significantly, the Share variable, and the Share variable significantly influence the Investment Decision variable. Further information can be seen at the following explanation points:

\begin{tabular}{|c|c|c|c|}
\hline Variables & T-Statistik & T-Tabel & Information \\
\hline Attention & 2,288 & 1.96 & $\begin{array}{c}\text { Has a significant } \\
\text { effect }\end{array}$ \\
\hline Interest & 2,530 & 1.96 & $\begin{array}{c}\text { Has a significant } \\
\text { effect }\end{array}$ \\
\hline Action & 2,913 & 1.96 & $\begin{array}{c}\text { Has a significant } \\
\text { effect }\end{array}$ \\
\hline Share & 8,235 & 1.96 & $\begin{array}{c}\text { Has a significant } \\
\text { effect }\end{array}$ \\
\hline
\end{tabular}

Source: Data processed in 2020

\section{The Effect of Attention on Interest}

In this study the Attention variable is proxied by three indicators, including messages to investors (X1.1), investors know the product (X1.2), and Word of Mouth (X1.3), but in this study, only two indicators passed. at the evaluation stage of the measurement model (outer model), namely the message to the investor (X1.1), the investor knows the product (X1.2). Based on the tstatistical value table obtained in the Attention to Interest variable, it is 2.288, 
Jurnal Ekonomi dan Perbankan Syariah

Vol. 8. No.1, April 2020: 28-43 ISSN (printed): 2355-1755 | ISSN (online): 2579-643

where this value is greater than the t-table of 1.96. Thus, it can be concluded that $\mathrm{H} 0$ is rejected and $\mathrm{H} 1$ is accepted. These results indicate that the Attention variable has a significant effect on Interest.

\section{Effect of Interest on Search}

In this study, the Interest variable is proxied by five indicators, including interest in the product after the message reaches the investor (X2.1), interest in the product (X2.2), application of sharia principles (X2.3), ease of transaction (X2.4) ), the current trend (X2.5). In this study the indicators that passed the evaluation stage of the measurement model (outer model) included interest in the product after the message arrived at the investor (X2.1), interest in the product (X2.2), application of sharia principles (X2.3), ease transaction (X2.4). Based on the t-statistical value table obtained in the Interest to Search variable of 2.530 , this value is greater than the t-table of 1.96 . Thus, it can be concluded that $\mathrm{H} 0$ is rejected and $\mathrm{H} 1$ is accepted. These results indicate that the Interest variable has a significant effect on Search.

\section{Effect of Search on Action}

In this study, the Search variable is proxied by seven indicators, including visiting the website (X3.1), further search (X3.2), application of sharia principles (X3.3), sharia principles (X3.4), profit (X3. 5), risk (X3.6), investors trust the information obtained (X3.7). In this study, there are three indicators that pass the evaluation stage of the measurement model (outer model), including visiting the website (X3.1), applying sharia principles (X3.3), sharia principles (X3.4). Based on the t-statistical value table obtained in the Search for Action variable of 7.167 where the value is greater than the t-table of 1.96. Thus, it can be concluded that $\mathrm{H} 0$ is rejected and $\mathrm{H} 1$ is accepted. These results indicate that the Search variable has a significant effect on Action.

\section{Effect of Action on Share}

In this study, the Action variable was proxied by eight indicators, including the desire of investors to invest (X4.1), investors considering investing (X4.2), consideration of sharia principles (X4.3), consideration of the absence of maysir / gambling elements (X4 .4), consideration of the absence of an element of usury (X4.5), consideration of the absence of gharar (X4.6), profits (X4.7), investors investing (X4.8).

In this study there are four indicators that pass the evaluation stage of the measurement model (outer model), including consideration of sharia principles (X4.3), consideration of the absence of elements of maysir / gambling (X4.4), consideration of the absence of elements of usury (X4.5), considering the absence of the element of gharar (X4.6). Based on the t-statistic value table obtained in the Action to Share variable, it is 2.913 where the value is greater than the t-table of 1.96. Thus, it can be concluded that $\mathrm{H} 0$ is rejected and $\mathrm{H} 1$ is accepted. These results indicate that the Action variable has a significant effect on Share. 
41 |lin Mega Nur Janah, Iqbal Fadli Nuhammad, Muhammad Doddy : The Effect of EMarketing with the AISAS Model on Sharia Mutual Fund Investment Decision...

5. The effect of shares on investment decisions

In this study, the Share variable is proxied by two indicators, including providing reviews on social media (X5.1) and disseminating information to family or society (X5.2). In this study, all indicators passed the evaluation stage of the measurement model (outer model). Based on the tstatistical value table obtained in the Share variable on investment decisions of 8,235 where this value is greater than the t-table of 1.96 . Thus, it can be concluded that $\mathrm{H} 0$ is rejected and $\mathrm{H} 1$ is accepted. These results indicate that the Share variable has a significant effect on Investment Decisions.

\section{CONCLUSION}

Based on the results of this study, it can be seen that e-marketing is very influential in the decision to invest in Islamic mutual funds fintech. Based on testing, analysis and discussion, it can be concluded in more detail that:

a) The Attention variable has a significant effect on the Interest variable, this is possible because of the interest of investors in sharia mutual fund investments due to the interesting messages given to potential investors, so that investors are interested in Islamic mutual fund investment products.

b) Interest variable significantly influences the Search variable, this is possible due to investor interest in sharia mutual fund products, thus encouraging to find out more information about sharia mutual fund investment products.

c) The Search variable has a significant effect on the Action variable, this is in accordance with the results of previous research which states that the Search indicator has an effect on Action. This is due to the ease of obtaining information, so that investors will find it easier to find Islamic mutual fund investment products.

d) The Action variable has a significant effect on the Share variable, this is possible because investor satisfaction with mutual fund investment products encourages investors to share information, according to the Word of Mouth theory.

e) Variable Share significantly influences the Investment Decision variable, according to the Word of Mouth theory, that the dissemination of information is very influential on a decision.

Respondents of this study invested in PT Bibit Tumbuh Bersama, this was because the company was very active in disseminating information in the form of mutual fund product promotions through social media. Therefore, it has an impact on public knowledge about the platform. 
Jurnal Ekonomi dan Perbankan Syariah

Vol. 8. No.1, April 2020: 28-43 ISSN (printed): 2355-1755 | ISSN (online): 2579-643

\section{BIBLIOGRAPHY}

Abdillah, W., \& Hartono, J. (2015). Partial Least Square (PLS)- Alternatif Structural Equation Modeling (SEM) dalam Penelitian Bisnis. (D. Prabantini, Ed.). C.V Andi Offset.

Amer, D., Barberis, J., \& Buckley, R. p. (2016). The Evolution Of Fintech: A New Post-Crisis Paradigm?, 2015(047).

APJII. (2019a). Buletin APJII (Survei APJII yang Ditunggu-tunggu, Penetrasi Internet Indonesia 2018), 1. Retrieved from https://apjii.or.id/survei

APJII. (2019b). Bulletin APJII- Memacu Jumlah Unicorn Indonesia.

Bank Indonesia. (2017). PPBI No. 19/12/pbi/2017 tentang Penyelenggaraan Teknologi Finansial.

DSN-MUI. (2018). Fatwa Dewan Syariah Nasional-Majelis Ulama Indonesia No: 117/DSN-MUI/II/2018 Tentang Layanan Pembiayaan Berbasis Teknologi Informasi Berdasarkan Prinsip Syariah, 14.

Dz, A. S. (2018). Inklusi Keuangan Perbankan Syariah Berbasis DigitalBanking : Optimalisasi dan Tantangan. Jurnal Al-Amwal, 10(1).

Fariana, A., \& Safii, A. (2018). Sinergi Fintech Dengan Perbankan Syariah Dalam Perspektif Hukum. Jurnal Hukum Dan Ekonomi Islam, 17(2), 259-475.

Harefa, alvani amaerita, \& Kennedy, posmasariguna johnson. (2018). Financial Technology, Regulasi dan Adaptasi Perbankan di INdonesia. Journal of Fundamental Management, 3(1), 1-11.

Liputan 6. (2019). Ada Fintech, Transaksi Reksa Dana via Online Capai Rp 5 Triliun. Retrieved from https://www.liputan6.com/bisnis/read/4009382/ada-fintech-transaksireksa-dana-via-online-capai-rp-5-triliun

OJK. (2017). Kajian Perlindungan Konsumen Sektor Jasa Keuangan: Perlindungan Konsumen Pada Fintech. Departemen Perlindungan Konsumen.

OJK. (2019). Perkembangan Fintech Lending (Pendanaan Gotong Royong onLine). Otoritas Jasa Keuangan. Retrieved from https://www.ojk.go.id/id/berita-dan-kegiatan/siaranpers/Documents/Pages/Siaran-Pers-Satgas-Kembali-Temukan-182Fintech-Peer-To-Peer-Lending-Tanpa-Izin

Priyono. (2016). Metode Penelitian Kuantitatif. Zifatama Publishing.

Republika. (2018). Fintech Dongkrak Penjualan Reksadana di Kalangan Milenial. Republika.Co.Id, p. 2. Retrieved from https://reppubliks.co.id/berita/pggutp383/fintech-dongkrak-penjualanreksa-dana-di-kalangan-milenial

Riskinanto, A., Kelana, B., \& Hilmawan, D. R. (2017). The Moderation Effect of Age on Adopting E-Payment Technology. In Journal of Procedia Computer Science (Vol. 124, pp. 536-543). Elsevier B.V. https://doi.org/10.1016/j.procs.2017.12.187

Sugiyama, K. (2011). Secrets of Cross Switch Marketing from the World. Dentsu inc. 
43 lin Mega Nur Janah, Iqbal Fadli Muhammad, Muhammad Doddy : The Effect of EMarketing with the AISAS Model on Sharia Mutual Fund Investment Decision...

Technologue.id. (2018). OJK Dukung Fintech dan Marketplace pada Investasi Reksadana. Retrieved from https://technologue.id/ojk-dukung-fintechdan-marketplace-pada-investasi-reksadana/amp/

Umar, H. (2013). Metode Penelitian untuk Skripsi dan Tesis Bisnis (Kedua). PT RajaGrafindo Persada.

Wiley, J. (2017). Metode Penelitian untuk Bisnis (keenam). Salemba Empat.

Wisnu, W., \& Hapsari, P. D. (2016). Analisis AISAS Model Terhadap Product Placement Dalam Film Indonesia Studi Kasus: Brand Kuliner di Film Ada Apa Dengan Cinta 2. Jurnal Rekam, 12(2), 69-81. Retrieved from http://journal.isi.ac.id/index.php/rekam/article/viewFile/1424/294 